\title{
A nonsense mutation in the tyrosinase gene of Afghan patients with tyrosinase negative (type IA) oculocutaneous albinism
}

\author{
Lutz B Giebel, Maria A Musarella, Richard A Spritz
}

\begin{abstract}
We detected a nonsense mutation in the tyrosinase gene of two Afghan sibs with classical tyrosinase negative (type IA) oculocutaneous albinism. The mutation, a single base substitution at codon 178, creates an amber termination codon that truncates the 529 amino acid tyrosinase polypeptide at this position. The patients' parents are first cousins, and the patients are therefore homoallelic for this mutation.
\end{abstract}

Oculocutaneous albinism (OCA) is a heterogeneous group of severe, autosomal recessive inherited disorders of pigmentation. In OCA the amount of melanin is reduced or absent in pigment cells of the skin, hair follicle, and eye. Hypopigmentation of the retina is associated with decreased visual acuity, photophobia, and varying degrees of nystagmus. In patients with classical (type IA) OCA, absent melanin biosynthesis results from absent activity of melanocyte tyrosinase (monophenol, L dopa:oxygen oxidoreductase, EC 1.14.18.1). Tyrosinase is a copper containing enzyme that catalyses the first two steps of the melanin biosynthetic pathway: the hydroxylation of tyrosine to dihydroxyphenylalanine (dopa) and the subsequent oxidation of dopa to dopa-quinone. ${ }^{12}$

Several human tyrosinase cDNAs have been cloned $^{3-5}$ and the 529 amino acid sequence has been deduced. The first $18 \mathrm{~N}$-terminal amino acids constitute a leader peptide which is removed to yield

Departments of Medical Genetics and Pediatrics, University of Wisconsin, Madison, WI, USA.

L B Giebel, R A Spritz

Department of Ophthalmology, Hospital for Sick Children Research Institute, Toronto, Ontario, Canada.

M A Musarella

Correspondence to Dr Spritz, 309 Laboratory of Genetics, University of Wisconsin, 445 Henry Mall, Madison, WI 53706, USA.

Received for publication 6 November 1990.

Revised version accepted for publication 31 December 1990. the mature $58 \mathrm{kd}$ highly glycosylated tyrosinase enzyme. ${ }^{6}$ The deduced amino acid sequence contains five potential asparagine linked glycosylation signals, two potential copper binding sites, and a C-terminal potential transmembrane region. ${ }^{3}$ The human tyrosinase gene is located on chromosome segment 1lq14 $\mathrm{q} 21^{7}$ and consists of five exons spanning more than $50 \mathrm{~kb}$ of DNA. ${ }^{8}$

Seven different mutations of the tyrosinase gene have been described in patients with type IA OCA. These include a frameshift mutation (codon 310$)^{9}$ and a missense mutation (codon $77 \mathrm{Arg} \rightarrow \mathrm{Gln})^{10}$ in Japanese patients, a frameshift mutation (codon $501)^{11}$ and three different missense mutations (codon 81 Pro $\rightarrow$ Leu, ${ }^{12}$ codon $373 \mathrm{Thr} \rightarrow$ Lys, and codon 383 Asp $\rightarrow$ Asn $)^{13}$ in Caucasian patients, and one missense mutation (codon $89 \mathrm{Cys} \rightarrow \mathrm{Arg})^{14}$ in an American Black. Here we describe an eighth tyrosinase gene mutation associated with type IA OCA, an amber nonsense mutation at codon 178 ( $\mathrm{Trp} \rightarrow \mathrm{Ter}$ ), in two sibs of Afghan ethnic origin. The patients' parents are first cousins and both patients are homoallelic for the codon 178 nonsense mutation.

\section{Materials and methods}

DESCRIPTION OF PATIENTS

The two patients, a brother (patient 1) and sister (patient 2), are the offspring of a consanguineous marriage of first cousins of Afghan ethnic origin. The patients' parents, a brother, and three sisters are darkly pigmented. Although hairbulb tyrosinase activity was not determined, both affected children exhibit classical features of type IA oculocutaneous albinism, completely lacking apparent melanin pigment in their hair, skin, and eyes. Their irides are pale blue and transilluminate completely, and their retinae are unpigmented. Their visual acuity is greatly reduced, with foveal hypoplasia, constant nystagmus, and photophobia. Patient 1 also has trisomy 21 .

Enzymatic assay of freshly epilated anagen hairbulbs $^{2}$ from patient 1 showed no detectable tyrosinase activity. 
POLYMERASE CHAIN REACTION (PCR) AND DNA SEQUENCING

Genomic DNA was isolated from peripheral blood leucocytes $^{15}$ of both patients and tyrosinase gene fragments corresponding to the five exons plus flanking sequences ${ }^{8}$ of the male sib (patient 1) were PCR amplified from $0.1 \mu \mathrm{g}$ DNA in $100 \mu \mathrm{l}$ volumes of $10 \mathrm{mmol} / \mathrm{l}$ Tris- $\mathrm{HCl}, \mathrm{pH} 8.3,50 \mathrm{mmol} / \mathrm{l} \mathrm{KCl}, 1.5$ $\mathrm{mmol} / 1 \mathrm{MgCl}_{2}, 200 \mu \mathrm{mol} / \mathrm{l}$ of each dNTP, $100 \mu \mathrm{g} / \mathrm{ml}$ gelatin, $100 \mathrm{pmol}$ of each primer (table), and 2.5 U Taq DNA polymerase (Perkin-Elmer Cetus, Norwalk, CT) using an automated thermal cycler (Coy Laboratory Products Inc, Ann Arbor, MI). Each of 40 cycles consisted of 30 seconds at $94^{\circ} \mathrm{C}$, one minute at $50^{\circ} \mathrm{C}$, and two minutes at $72^{\circ} \mathrm{C} .{ }^{17} \mathrm{Ampli}-$ fication products were gel purified, subcloned into bacteriophage vectors $\mathrm{M} 13 \mathrm{mp} 18$ or $\mathrm{mpl9}$, and their nucleotide sequences were determined. ${ }^{18}$

\section{RESTRICTION ENZYME CLEAVAGE ANALYSIS}

Tyrosinase gene exon 1 DNA fragments of both patients and also of eight normal persons of northern European Caucasian origin were amplified by PCR using oligonucleotide primers P11 and P12 (table). PCR amplification products were then digested with $X b a I$ and analysed by polyacrylamide gel electrophoresis for the presence of the codon 178 nonsense mutation. The exon 1 PCR products of the two patients were also digested with $M b o I$ to analyse a polymorphism at codon $192 .{ }^{19}$

\section{Results}

IDENTIFICATION OF THE TYROSINASE GENE CODON 178 MUTATION

To define the molecular basis of the type IA (tyrosinase negative) OCA in the two sibs of Afghan origin, we analysed their tyrosinase genes by PCR amplification, molecular cloning, and subsequent DNA sequencing. Each of the five tyrosinase exons plus adjacent noncoding sequences was amplified from genomic DNA of patient 1 using oligonucleotide primers (table) derived from the DNA sequence of the normal human tyrosinase gene. ${ }^{816}$ As shown in fig 1 , nucleotide sequence analysis of the PCR products showed only a single difference from normal, a base substitution at codon 178: TGG (Trp) $\rightarrow$ TAG (Ter). This amber codon would result in termination of translation of the corresponding tyrosinase mRNA at this position.

The coding region of normal human tyrosinase genes exhibits two common non-pathological polymorphisms. Codon 192 can encode either tyrosine (TAT) or serine (TCT), ${ }^{19}$ and codon 402 can encode either arginine (CGA) or glutamine (CAA). ${ }^{20}$ The codon 192 polymorphism is also an RFLP for the restriction enzyme $M b o I$ (TAT: no $M b o I$ site, TCT: MboI site). Therefore, 338 bp PCR products corresponding to part of exon 1 were amplified from genomic DNA of both patients using primer pair P11/P12, digested with $M b o I$, and were analysed by polyacrylamide gel electrophoresis for the presence of the polymorphic MboI site (data not shown). Both probands were found to be homozygous for TCT (Ser) at this codon. The polymorphism at codon 402 is not an RFLP; therefore, we sequenced six independent exon $4 \mathrm{M} 13$ subclones from patient 1 and found that he is also homozygous for codon 402 CGA (Arg).

BOTH PATIENTS ARE HOMOZYGOUS FOR THE CODON 178 NONSENSE MUTATION

The codon 178 TGG $\rightarrow$ TAG nonsense substitution creates a new restriction site for $\mathrm{XbaI}$ (TCTAGA).

Oligonucleotide primers used for amplification of tyrosinase gene exons by PCR.

\begin{tabular}{llll}
\hline Primer & \multicolumn{1}{c}{ Sequence } & \multicolumn{1}{c}{ Position ${ }^{*}$} & \multicolumn{1}{c}{ Sequence amplified } \\
\hline P1 & 5'-GCTCTTTAACGTGAGATATC-3' & $-40--21 \dagger$ & $\begin{array}{c}\text { Exon 1 plus adjacent regions } \\
\text { and promoter }\end{array}$ \\
P2 & 5'-TTATACCCTGCCTGAAGAAG-3' & $1543-1562 \mathrm{c}$ & Exon 2 plus adjacent regions \\
P3 & 5'-CTCAGGAGAAGTCTAACAAC-3' & $1644-1663$ & \\
P4 & 5'-AACTCAGAAATTCTGAATTC-3' & $2049-2068 \mathrm{c}$ & Exon 3 plus adjacent regions \\
P5 & 5'-GAGTCTCAATACGGAATGAA-3' & $2153-2172$ & \\
P6 & 5'-TTTAAATCCAATGAGCACGT-3' & $2470-2489 \mathrm{c}$ & Exon 4 plus adjacent regions \\
P7 & 5'-TTAATATATGCCTTATTTTA-3' & $2514-2533$ & \\
P8 & 5'-TAAAGTTTTGTGTTATCTCA-3' & $2842-2861 \mathrm{c}$ & Exon 5 plus adjacent regions \\
P9 & 5'-CTCCAAAGGACTGTGAAAGG-3' & $2963-2982$ & \\
P10 & 5'-GGAGTCAGTTAATGTAGATT-3' & $3661-3680 \mathrm{c}$ & Fragment of exon 1 \\
P11 & 5'-GCAAGTTTGGCTTTTGGGGA-3' & $979-998$ & $1297-1316 \mathrm{c}$ \\
P12 & 5'-CAAGAAGAGTCTATGCCAAG-3' & &
\end{tabular}

*Nucleotide positions refer to sequence of Giebel et al. ${ }^{8}$

†This primer was derived from the sequence of Kikuchi $e t a l^{16}$; its position is enumerated relative to the sequence of Giebel $e t a l{ }^{8}$ $c$ indicates that primer sequence is complementary to that in fig 2 of ref 8 . 


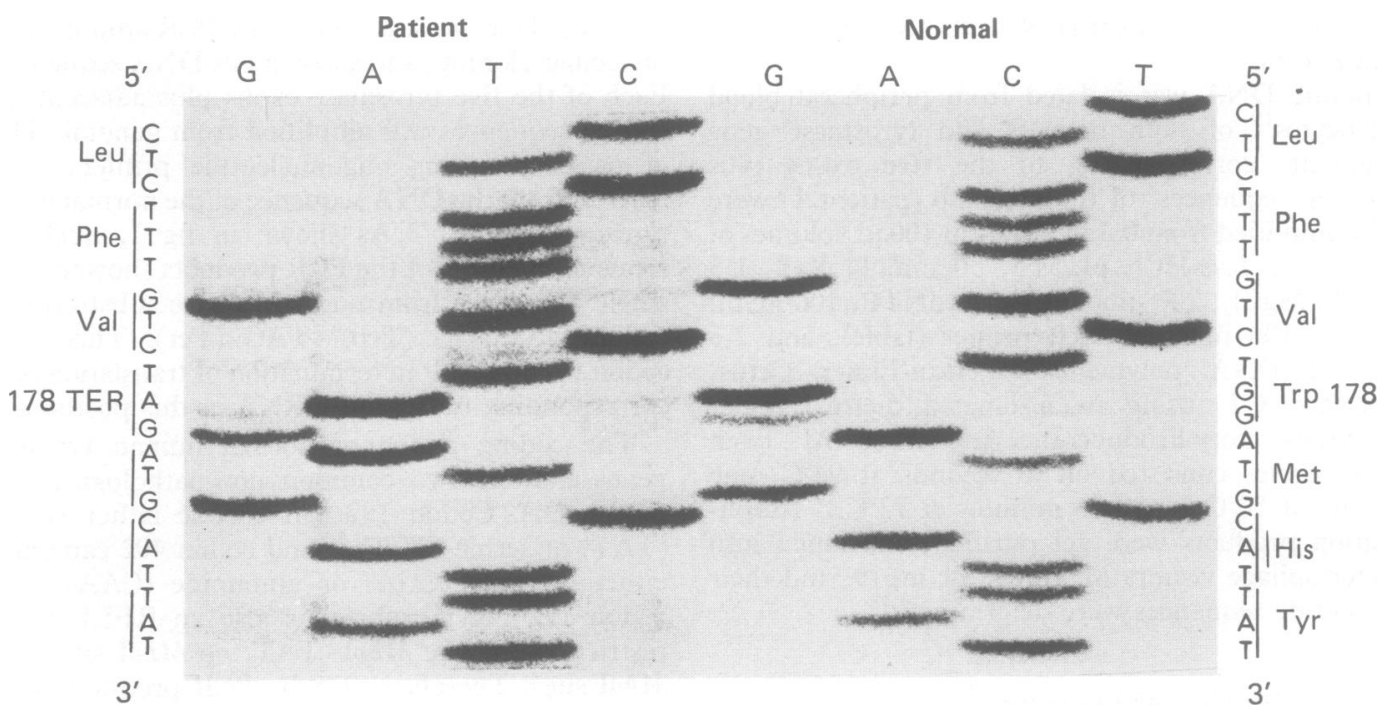

Figure 1 Sequences in the region of the codon 178 nonsense mutation from the patient and an unrelated normal person. The sequence shown is of the coding strand.

This enabled us to confirm the presence of this mutation in the patients' genomic DNA. A 338 bp fragment of the tyrosinase gene exon 1 was PCR amplified from genomic DNA of the two sibs with OCA and from eight unrelated, normal, Caucasian subjects using primer pair P11/P12. The fragments were then digested with $X b a \mathrm{I}$ and analysed by polyacrylamide gel electrophoresis (fig 2). The 338 bp exon 1 PCR products of all eight normal subjects contained no $X b a I$ site and thus were not cleaved by $X b a I$. However, the 338 bp fragments of both OCA patients were completely cleaved by $X b a I$ to 223 bp and $115 \mathrm{bp}$ fragments. This is consistent with their both being homoallelic for the codon $178 \mathrm{TGG} \rightarrow$ TAG nonsense substitution.

\section{Discussion}

Tyrosinase negative (type IA) oculocutaneous albinism, characterised by absent melanocyte tyrosinase activity, results from tyrosinase gene mutations that abolish tyrosinase enzymatic activity. ${ }^{9-14} \mathrm{We}$ have identified a new tyrosinase gene mutation in two Afghan sibs with type IA OCA. Both patients are homoallelic for a single base substitution (TGG $\rightarrow$ TAG) within codon 178, resulting in the change of a tryptophan codon to a translational termination codon. The resultant truncated 177 amino acid tyrosinase polypeptide would lack both of the putative copper binding sites and the putative transmembrane segment, ${ }^{3}$ and therefore would have no tyrosinase enzymatic activity and might even be subject to rapid

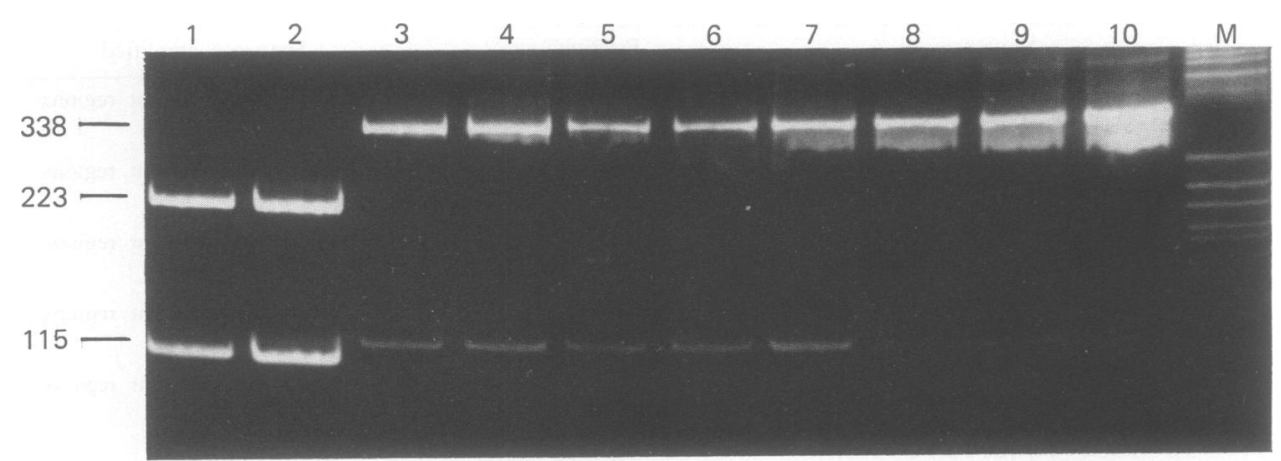

Figure 2 XbaI cleavage analysis of the codon 178 nonsense mutation. Exon 1 PCR products were amplified from DNA of patient 1 (lane 1), his affected sister (lane 2), and eight unrelated, normally pigmented subjects (lanes 3-10) and cleaved with XbaI. $M$, molecular size standard ( $p B R 322$ digested with Bst $N I+$ HaeIII). The approximately 120 bp PCR product is a non-tyrosinase related fragment that is amplified from all human genomic DNA by these primers and that is present before XbaI digestion. 
proteolytic degradation. The codon 178 substitution creates a new $X b a I$ restriction site, permitting simple identification of this substitution by either allele specific oligonucleotide hybridisation or $\mathrm{XbaI}$ cleavage analysis.

This work was supported by Clinical Research Grant 6-408 of the March of Dimes Birth Defects Foundation and Grant AR-39892 of the National Institutes of Health. This is paper number 3165 from the Laboratory of Genetics, University of Wisconsin, Madison.

1 King RA, Summers CG. Albinism. Dermatol Clin 1988;6:217-28.

2 Witkop CJ Jr, Fitzpatrick TB, King RA. In: Scriver CR, Beaudet $\mathrm{AL}$, Sly WS, Valle $\mathrm{D}$, eds. The metabolic basis of inherited disease. New York: McGraw-Hill, 1989.

$3 \mathrm{Kwon}$ BS, Haq AK, Pomerantz SH, Halaban R. Isolation and sequence of a cDNA clone for human tyrosinase that maps at the mouse c-albino locus. Proc Natl Acad Sci USA 1987;84: 7473-7.

4 Shibahara S, Tomita Y, Tagami H, Muller R, Cohen T. Molecular basis for the heterogeneity of human tyrosinase. Tohoku $\mathcal{7}$ Exp Med 1988;156:403-14.

5 Bouchard B, Fuller BB, Vijayasaradhi S, Houghton AN. Induction of pigmentation in mouse fibroblasts by expression of human tyrosinase cDNA. f Exp Med 1989;169:2029-42.

6 Wittbier A, Dahlback B, Odh G, Rosengren AM, Rosengren E Rorsman H. Isolation of human tyrosinase from cultured melanoma cells. Acta Dermatol Venereol (Stockh) 1989;69: 125-31.

7 Barton DE, Kwon BS, Francke U. Human tyrosinase gene mapped to chromosome $11(\mathrm{q} 14 \rightarrow \mathrm{q} 21)$, defines second region of homology with mouse chromosome 7. Genomics 1988;3: $17-24$.

8 Giebel LB, Strunk KM, Spritz RA. Organization and nucleotide sequence of the human tyrosinase gene and a truncated tyrosinase pseudogene. Genomics 1991;9:435-45.

9 Tomita Y, Takeda A, Okinaga S, Tagami H, Shibahara S. Human oculocutaneous albinism caused by single base insertion in the tyrosinase gene. Biochem Biophys Res Commun 1989;164: 990-6.

10 Kikuchi H, Hara S, Ishiguro S, Tamai $M$, Watanabe $M$. Detection of point mutation in the tyrosinase gene of a Japanese albino patient by a direct sequencing of amplified DNA. Hum Genet 1990;85:123-4.

11 Giebel LB, Tripathi RK, Strunk KM, et al. Tyrosinase gene mutations associated with type IB ("yellow") oculocutaneous albinism. Am 7 Hum Genet (in press).

12 Giebel LB, Strunk KM, King RA, Hanifin JM, Spritz RA. A frequent tyrosinase gene mutation in classic, tyrosinase-negative (type IA) oculocutaneous albinism. Proc Natl Acad Sci USA 1990;87:3255-8.

13 Spritz RA, Strunk KM, Giebel LB, King RA. Detection of mutations in the tyrosinase gene in a patient with type IA oculocutaneous albinism. N Engl F Med 1990;322:1724-8.

14 Spritz RA, Strunk KM, Hsieh CL, Francke U. Homozygous tyrosinase gene mutation in an American black with tyrosinasenegative (type IA) oculocutaneous albinism. Am $\mathcal{F}$ Hum Genet 1991;48:318-24.

15 Sambrook J, Fritsch EF, Maniatis T. Molecular cloning. A laboratory manual. Cold Spring Harbor, NY: Cold Spring Harbor Laboratory Press, 1989.

16 Kikuchi H, Miura H, Yamamoto H, Takeuchi T, Dei $T$, Watanabe $M$. Characteristic sequences in the upstream region of the human tyrosinase gene. Biochim Biophys Acta 1989;1009: 283-6.

17 Saiki RK, Gelfand DH, Stoffel S, et al. Primer directed enzymatic amplification of DNA with a thermostable DNA polymerase. Science 1988;239:487-91.

18 Sanger F, Nicklen S, Coulson AR. DNA sequencing with chain termination inhibitors. Proc Natl Acad Sci USA 1977;74: 5463-7.

19 Giebel LB, Spritz RA. RFLP for Mbo I in the human tyrosinase (TYR) gene detected by PCR. Nucleic Acids Res 1990;18:3103.

20 Tripathi RK, Giebel LB, Strunk KM, Spritz RA. A polymorphism of the human tyrosinase gene is associated with temperaturesensitive enzymatic activity. Gene Expression (in press). 